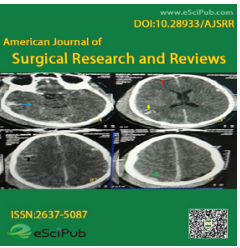

American Journal of Surgical Research and Reviews

(ISSN:2637-5087)

\title{
A novel technique to prevent the breast implant from exposure after mastectomies
}

Atif Rafique, (MBBS, FCPS plastic Surgery, EBPRAS); Ambreen Arshad (MBBS, MCPS); Fuad Hashem (MD, FRCSc)

Department of Surgery, King Faisal Specialist Hospital and Research Centre, Saudi Arabia

\section{ABSTRACT}

\section{Introduction}

After mastectomies, we do our reconstruction, either immediately or delayed. In both ways of reconstruction for post mastectomies defect, the most commonly performed reconstruction is by using breast prosthesis ${ }^{[1]}$. For many years, surgeons have been trying to find out any solution to reduce the rate of implant exposure and develop some new techniques and modifications. However, once the infection develops or implant expose the only permanent solution is to remove the implant ${ }^{[2-3]}$.

Although there is less evidence found in the literature regarding the salvage of implant once the infection occurs and when implant becomes expose in implant-based reconstruction ${ }^{[4]}$. Radiation also plays additional role in post-operative complication rates following implant-based breast reconstruction, as it is well documented that the incidence of complications is to be higher in radiated breasts compare to similar non-radiated breasts ${ }^{[5]}$. With the new advancement in radiation therapy the number of patients have been increasing who are receiving radiation therapy after immediate breast reconstruction ${ }^{[5]}$.

\section{Description of the Technique}

For more than 15 years we have been reconstructing the breasts deformities after different types of mastectomies, ranging from skin sparing, nipple areola sparing to different types of lumpectomies, by immediate insertion of breast implants.

The main problem which we face during post-reconstruction, is the exposure of implant in addition to infection. With the advent
*Correspondence to Author:

Atif Rafique, (MBBS, FCPS plastic Surgery, EBPRAS)

Department of Surgery, King Faisal Specialist Hospital and Research Centre, Saudi Arabia

How to cite this article:

Atif Rafique, Ambreen Arshad. Fuad Hashem. A novel technique to prevent the breast implant from exposure after mastectomies. American Journal of Surgical Research and Reviews, 2021; 4:14.

\section{eScîPub} eSciPub LLC, Houston, TX USA. Website: https://escipub.com/

By using the site/services, you are agreeing to our Policies:

https://escipub.com/terms-privacypolicy-disclaimer/ 
of ADM (Artificial Dermal Matrix) ${ }^{[6]}$, serratus anterior muscle ${ }^{[7]}$, rectus fascial flap ${ }^{[7]}$ and inferior dermal flaps ${ }^{[8]}$ although they do an addition to thickness of skin envelop over the implant after mastectomy, but still the rate of implant exposure has not changed noticeably. It has been well understood that of ADM expose in air it dries immediately which later on results in implant exposure.

Meanwhile we have developed a novel technique to augment the soft tissue coverage under the incision line over the ADM and implant. By this way, if there is any dehiscence over suture line, there will be no implant exposure as there is additional soft tissue layer of dermal flap. These dermal flaps are actually a de-epithelialized dermal flap from the inferior half of the breast skin, which we used to excise and throw it to the garbage, particularly in skin sparing mastectomies. In this technique we suture the inferior based dermal flap over the artificial dermal matrix in a way that suture lines of skin flaps of mastectomy lie over the de-epithelialized dermal flap, which actually in- crease the survivability of ADM as well as increase the thickness of soft tissue over the implant (figure 1 and 2).

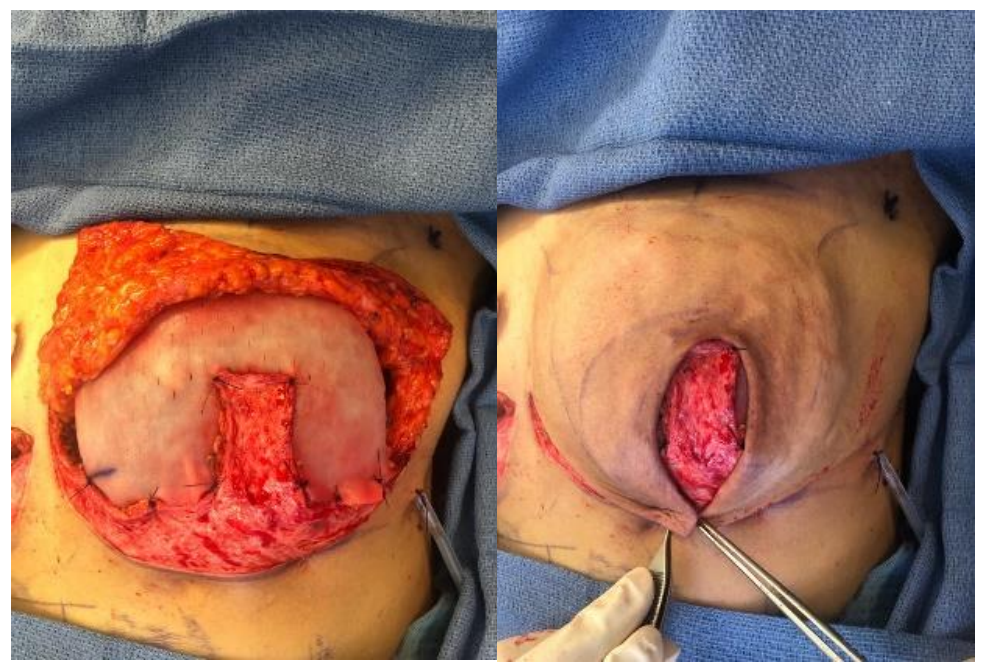

Figure 1)

(Figure 2)
By addition of this layer of de-epithelialized dermal flaps over the artificial dermal matrix and breast implants have promising reduction effect over implant exposure as well as it provides the additional vascularized soft tissue layer over the implant.
Although we are using dermal flap with ADM frequently in most of our skin spring mastectomies but we did this new technique in 2 patients till now with the mean follow up of 8 weeks till now there is not a single case report of implant exposure in those patients (figure 3 ).

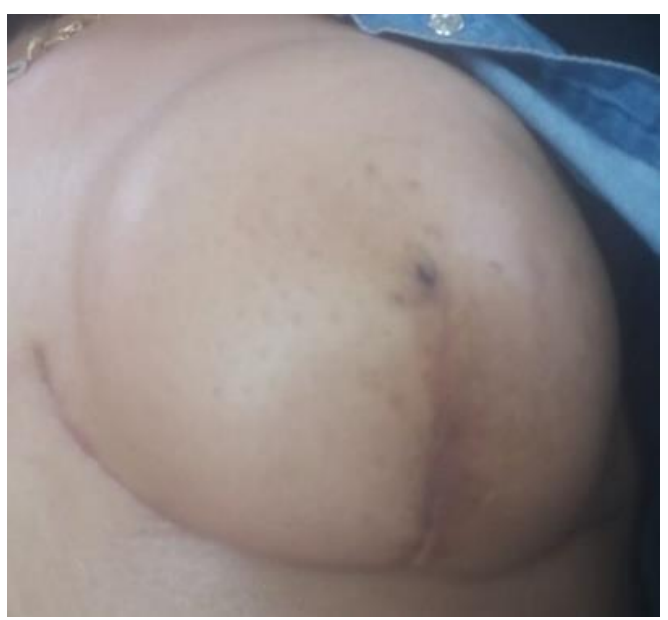

Figure 3 


\section{References}

[1] Gurunluoglu R, Gurunluoglu A, Williams SA, Tebockhorst $\mathrm{S}$. Current trends in breast reconstruction: survey of American Society of Plastic Surgeons 2010.Ann Plast Surg 2013;70(1):103-10.

[2] Nahabedian MY, Tsangris T, Momen B, Manson $\mathrm{PN}$. Infectious complication following breast reconstruction with expanders and implants. Plast Reconstr Surg 2003;112(2):467-76.

[3] McCarthy CM, Mehara BJ, Reidel E, Davidge K, Hinson A, Disa JJ, et al. Predicting complications following expander/implant breast reconstruction: an outcome analysis based on preoperative clinical risk. Plast Reconstr Surg 2008;121(6):188692.

[4] Spear SL, Onyewu C. Staged breast reconstruction with saline-filled implants in the irradiated breast: recent trends and therapeutic implication.Plast Reconstr Surg 2000; 105(3): 930-42.
[5] Gruber RP, Khan RA, Lash H, Maser MR, Apfeberg DB, Laub DR. Breast reconstruction following mastectomy: a comparison ofsubmuscular and subcutaneous techniques. Plast Reconstr Surg 1981;67(3):312-7.

[6] Breuing $\mathrm{KH}$, Warren SM. Immediate bilateral breast reconstruction with implants and inferolateral Alloderm slings. Ann Plast Surg 2005; 55:2329.10.1097/01.Sap0000168527.52472.3c[P ubMed][Crossref][Google Scholar]

[7] Sain-Cyr M, Dauwe P, Wong C, et al. Use of the serratus anterior fascia flap for expander coverage in breast reconstruction.Plast Reconstr Surg 2010;125:105764.10.1097/pRS.0b013e3181d17f 61[PubMed][CrossRef][Google Scholar]

[8] Bostwick J. Breast reconstruction after mastectomy. Recent advances. Cancer 1990;66:140211.10.1002/10970142(19900915)66:14+<1402:A ID-CNCR2820661416>3.0.CO;2-W[PubMed] [CrossRef][Google Scholar].

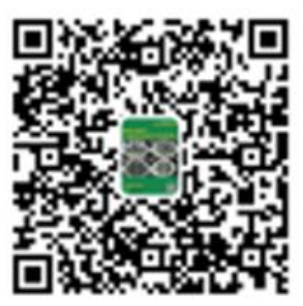

